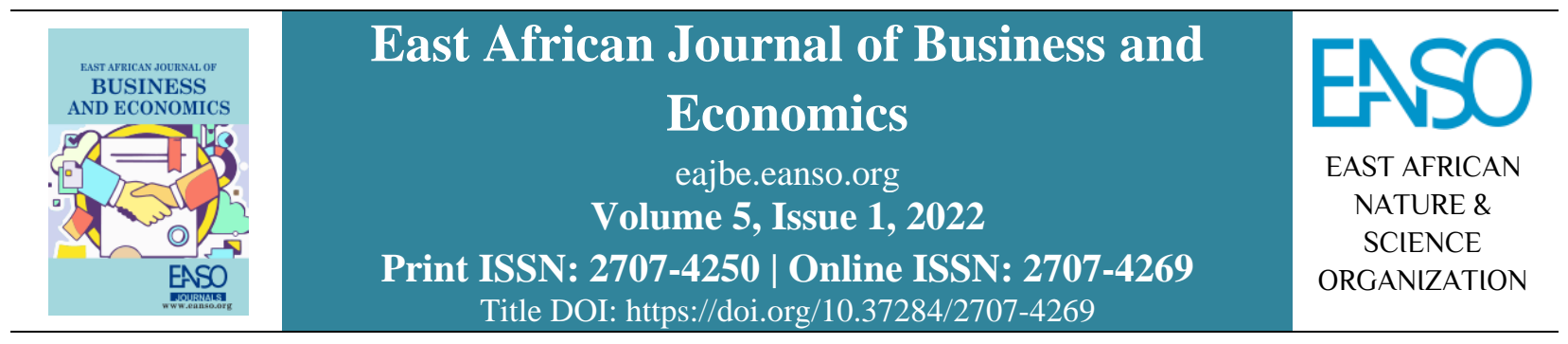

Original Article

\title{
Effects of Financial Statements Quality and Users' Knowledge on Decision Considerations and the Role of Satisfaction as a Potential Mediator.
}

\author{
Marie-Anne Razafiarivony, $P^{1} D^{1 *} \&$ Martina Hosna-Janeta ${ }^{1}$ \\ ${ }^{1}$ Adventist University of Africa, Private Bag Mbagathi, 00503, Nairobi, Kenya. \\ * ORCID: https://orcid.org/0000-0002-7297-2381; Correspondence email: razafiarivonymarie@ gmail.com.
}

Article DOI: https://doi.org/10.37284/eajbe.5.1.545

Date Published: ABSTRACT

09 February 2022 Financial statements are used in organisations as a source of financial information and are used as a tool in decision-making exercises that involve

Keywords: financial decisions. Financial statements indicate the organisations' current financial health and their future potential growth. Both for-profit and

Financial Statements, nonprofit organisations can benefit from such type of information. Studies

Decision-Making,

Decision-Making

Process,

show that there is a significant positive relationship between the use of financial statements and decision-making effectiveness. However, this situation is based on the premise that the financial information provided is of high quality and when those who have access to such information understand

Process Satisfaction, Decision Commitment. them and interpret them correctly. Reaching good decisions is vital for organisations, but the implementation of such decisions is equally crucial. Decision-makers need to commit to the decisions taken to reach the goals of the organisations. The decision-making process itself helps in reinforcing the commitment. It is hypothesised that the process is considered satisfactory when the goals set at the beginning of the meeting are met. The more satisfied the decision-makers feel about the process, the more committed they will be to the decisions. The relationship between the quality of the financial statement, the decision-makers knowledge, satisfaction with the decisionmaking process, and decision commitment has not been researched enough in not-for-profit organisations. Yet, these organisations are involved in complex decision-making situations since they have to balance their social mission and their fiscal responsibility. The study aims to analyse how satisfaction with the decision-making process mediates the effect of financial statements quality and their users' knowledge on the decision commitment in the not-for-profit context. It used a sample from selected not-for-profit entities from Liberia. The findings show that financial statements' quality is associated but does not affect the satisfaction with the decision-making process. On the other hand, satisfaction mediates the effect of knowledge on decision commitment. The findings seem to indicate that not-for-profit 
organisations need to prepare committee meetings with due diligence to reach optimal decisions and be able to gain full support to implement these decisions.

\section{APA CITATION}

Razafiarivony, M. A. \& Hosna-Janeta, M. (2022). 'Effects of Financial Statements Quality and Users' Knowledge on Decision Considerations and the Role of Satisfaction as a Potential Mediator. East African Journal of Business and Economics, 5(1), 3547. https://doi.org/10.37284/eajbe.5.1.545

\section{CHICAGO CITATION}

Razafiarivony, Marie-Anne \& Martina Hosna-Janeta. 2022. "Effects of Financial Statements Quality and Users' Knowledge on Decision Considerations and the Role of Satisfaction as a Potential Mediator". East African Journal of Business and Economics 5 (1), 35-47. https://doi.org/10.37284/eajbe.5.1.545.

\section{HARVARD CITATION}

Razafiarivony, M. A. \& Hosna-Janeta, M. (2022) "Effects of Financial Statements Quality and Users' Knowledge on Decision Considerations and the Role of Satisfaction as a Potential Mediator", East African Journal of Business and Economics, 5(1), pp. 35-47. doi: 10.37284/eajbe.5.1.545.

\section{IEEE CITATION}

M. A. Razafiarivony, \& M. Hosna-Janeta,. "Effects of Financial Statements Quality and Users' Knowledge on Decision Considerations and the Role of Satisfaction as a Potential Mediator", EAJBE, vol. 5, no. 1, pp. 35-47, Feb. 2022.

\section{MLA CITATION}

Razafiarivony, Marie-Anne \& Martina Hosna-Janeta. "Effects of Financial Statements Quality and Users' Knowledge on Decision Considerations and the Role of Satisfaction as a Potential Mediator". East African Journal of Business and Economics, Vol. 5, no. 1, Feb. 2022, pp. 35-47, doi:10.37284/eajbe.5.1.545.

\section{INTRODUCTION}

Strategic decision-making addresses critical issues and often involves using a significant amount of resources, including financial resources (Osadchy et al., 2018). One of an organisation's tools to communicate its financial situation is financial statements (Akhtar \& Liu, 2018). They indicate to the stakeholders the enterprise's current financial health and future potential growth and sustainability and help decision-makers make an informed economic decision of prediction and confirmation (Harrison et al., 2014). This type of information is crucial for both for-profit and nonprofit organisations since it helps the organisation gauge its financial capacity (Brinckerhoff, 2009). Many critical aspects of the organisation's operations, such as the anticipation of liquidity needs, the development of human resources, and future strategic moves, are decided upon from an in-depth analysis of financial statements. Several studies have researched the relationship between financial statement use and effective decision-making and found a significant positive relationship between these variables (Ullah et al., 2014; Akhtar \& Liu, 2018; Carraher \& Van Auken, 2013). Based on this reasoning, it is expected that the financial statements are high quality and that the decisionmakers understand and know how to interpret the data presented to make good decisions (Carraher and Van Auken, 2013). However, making good decisions is not enough. The decision-making process itself plays a role in enhancing the commitment. In particular, the decision-makers' satisfaction with the process contributes to more commitment to the decision (Ziotti \& Leoneti, 2020). The decision-makers will experience satisfaction with the decision-making process when the goals they set at the beginning of the meeting are met (Reinig, 2003). Once the decisions are made, the decision-makers must remain committed to the successful implementation of those decisions. The stronger the commitment to the decision, the higher the chances of successful implementation (Dooley et al., 2000).

All organisations, whether for-profit or not-forprofits, need adequate financial resources to reach 
their overarching goals. While this reality is in sharp focus in the for-profit setting, it tends to be more complex in the not-for-profit setting. Not-for-profit organisations are accountable to those who entrust them with resources to fulfil their mission (Wolf, 2012). The organisation's effectiveness is measured through the impact it is expected to make in the community through its program. Not-for-profit organisations are expected to balance fulfilling their social mission and fiscal responsibility (McDonald et al., 2015), and the managers of these entities know that financial sustainability can severely hinder the accomplishment of the mission (Brinckerhoff, 2009). Their performance is measured by the outcomes of the organisation's programs and its financial sustainability (Worth, 2019). In the last decades, the not-for-profits have experienced increasing difficulty to stay afloat financially. Several factors explain this challenge. In particular, an increase in the number of not-forprofit organisations has created more competition in the search and request for funding from donors (McDonald et al., 2015). There is also an increase in the demand for the services of such organisations (Sontag-Padilla et al., 2012). Hence, they must make the best decisions on how to manage their funds effectively and efficiently. Yet, again, it is not just a matter of making good decisions. The commitment to stand by the decisions is essential, as it determines the successful implementation of such decisions. The decision-making process matters, too, because when the decision-makers are satisfied with the way the decisions are made, the level of commitment is heightened (Ziotti \& Leoneti 2020). The relationship of such elements has not been researched enough in the context of not-forprofit organisations. This study endeavours to fill this gap. Its purpose is to analyse how the satisfaction with the decision-making process mediates the effect of financial statements quality and their users' knowledge on the decision commitment in the not-for-profit context.

The study uses the following research questions:
- What effect do the financial statements' quality and decision-makers' knowledge have on the decision commitment?

- To what extent does the satisfaction with the decision process mediate the relationship between the quality of financial statements and decision-makers' knowledge and decision commitment?

\section{REVIEW OF LITERATURE}

\section{Decision-making}

The study is anchored on the rational decisionmaking theory. This theory is chosen because of the nature of the decisions taken by the deciders. When stakes are high, rational decision-making is preferred over the intuitive decision-making model (Uzonwanne, 2016). The rational style, according to Russ et al. (1996), is "deliberate, analytical and logical; rational decision-makers assess the longterm effects of their decisions and have a strong fact-based task orientation to decision-making" (p. $5)$. When the decisions have a significant impact on the organisation's future, executives tend to be more careful and more rational in the way they proceed to reach a conclusion (Papadakis, Lioukas, and Chambers (1998 as cited in Nutt and Wilson, 2010). Each decision-maker is responsible for using the available information, analysing it, and subsequently selecting the best course of action to be taken (Wolf, 2012). The facts are gathered from available and good quality information that provides the decision-makers with an accurate perception of the situation on hand (Dean and Sharfman, 1996; Simons et al., 1999).

\section{Financial Statements - Types and Use}

One of the most critical decisions organisations need to make concerns the use of their financial resources. Poor financial decisions lead to financial distress and bankruptcy (Carraher and Van Auken, 2013). Financial statements are the primary tools for communicating the organisation's financial 
activities to its users for decision-making (Shagari \& Dandago, 2013). The International General Accepted Accounting Principles (GAAP) require the following to be included in any general-use financial statements, which are intended to focus on the organisation as a whole: Statement of Financial Position (or Balance Sheet); Statement of Financial Activity (or Income Statement); Statement of Changes in Net Assets; Statement of Cash Flows; Notes to the Financial Statements. Since the 1990s, the Financial Accounting Standards Board (FASB) has issued guidelines and language into nonprofit accounting adhered to by those organisations. In the nonprofit setting, financial statements provide information about the source of funds and their employment and enable the decision-maker to evaluate the organisation's ability to carry out its plans for the future per its mission (Worth, 2019; Lang et al., 2017).

\section{Financial Statements Quality}

Financial statements are expected to provide useful financial information to management. Quality financial statements contain appropriate information to help use past events to better shape the present and influence the future (Shagari \& Dandago (2013). Several features characterise quality financial statements. Accuracy has to do with the source, component, and credibility of the information and helps forecast the organisation's future (Shalimova and Kuzmenko (2016). Relevancy is when the information meets the task at hand or is adequate to the task. Timeliness is related to the usefulness of financial statement information. The quicker the required information is provided to the users, the more benefit they can derive from it (Türel, 2010). If the information needed is made available only after a decision must be made, it loses both its capacity to influence the decision and relevance altogether (Wang'ombe, 2005).

\section{Knowledge of the Users}

Even if the financial statement's quality is high calibre, it would still be useless for an effective decision without the decision maker's ability to understand the information. The first and primary task of the users of financial statements is to read and interpret the financial statements (Zager \& Zager, 2006). According to Zayol et al. (2017), understandability has to do with a familiarity with the way the financial statements are presented. A user who is not familiar with the format of financial statements and the terminologies used may overlook pertinent information or may not appreciate their relevance to the decision on hand. Vanauken et al. (2017) studied SMEs' use of financial statements for decision-making in Turkey and identified experience, confidence, and knowledge as key variables determining financial statements' use. On the other hand, in their study, Santos et al. (2018) show that the deciders' knowledge does not guarantee that the financial statements information will be used as a basis for decision-making.

\section{Satisfaction with the Decision Process}

The decision-making process is as important as the outcome of the decision taken (Dean \& Sharfman, 1996). The meeting process refers to the procedures, deliberations, and methods a group uses throughout a meeting. Satisfaction is a subjective yet vital element of the decision-making process. It involves the individual's emotional and affective components and whether the individual's expectations are met (Carneiro et al., 2014). According to Reinig (2003), decision-makers obtain satisfaction from a meeting when they agree and accept the goals set at the beginning of the meeting and when these goals are met as the meeting proceeds. Other studies point to other sources of decision satisfaction: the quality of the information available (Bharati \& Chaudhury, 2004), the decision-makers' perception of their abilities (knowledge) to accomplish the task (de la Torre-Ruiz et al., 2014). In our context, that would mean the knowledge of the deciders on how to 
interpret the information provided by the financial statements helps them advance good ideas and solutions to the debate and increases their level of satisfaction with the decision-making process. According to Paul et al. (2003), the users' training can contribute to the satisfaction with the decisionmaking. One of the rational decision theory tenets is decision-making comprehensiveness, where several alternatives are considered, and the best one is chosen in the end (Simons et al., 1999). Decisionmaking comprehensiveness creates a more cordial atmosphere and positively influences individual satisfaction (de la Torre-Ruiz et al., 2014), which in turn affects the level of decision commitment.

\section{Decision Commitment}

Decision commitment is concerned with the extent to which the decision-makers exert effort to see the decision being successfully implemented (Bandura, 1986 as cited in Dooley and Fryxell, 1999). The commitment of the decision-makers enables them to take initiatives and implement the decision made. Several factors seem to contribute to decision commitment. One of them is a well-structured group decision-making process where the team members participate in the discussions (Ziotti and Leoneti, 2020). The decision-makers' competence to address the concerns and questions raised during the discussion also plays a part in the commitment (Dooley and Fryxell, 1999). However, commitment can also be against change when needed because of the decision-makers' stand regarding the decision (Harrison \& Killough, 2006). Overconfidence in the decision creates an escalation of commitment, whereby decision-makers decide to pursue a course of action despite pieces of evidence of future failures (Drummond, 2014). In that case, commitment can be detrimental to the organisation's progress.

The following conceptual framework is proposed:
Independent Variables

\begin{tabular}{|l|}
\hline Quality of FS \\
Knowledge of \\
decision-makers \\
\hline
\end{tabular}

\section{Mediating Variable}

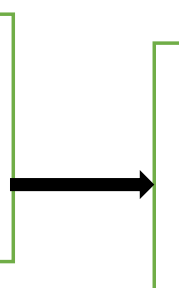

\section{Dependent Variable}

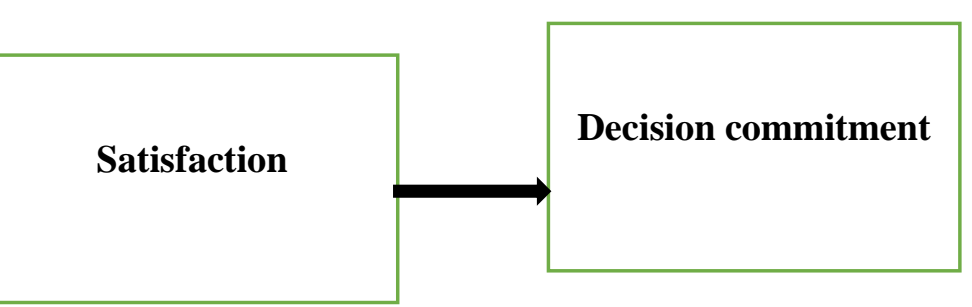

The independent variables used for this study are quality measured by accuracy, completeness and timeliness, and relevance. In addition to the quality of financial statements, the decision-makers' knowledge of reading and interpreting the information is another independent variable. The dependent variable is the level of decision commitment. The study posits that both quality and knowledge affect the decision commitment, but only if there is satisfaction with the decision-making process. Thus, satisfaction would be a possible mediating variable.

\section{METHODOLOGY}

The study used a causal analytical design to understand the relationship between financial statement quality, decision makers' knowledge, and decision commitment. This design was deemed appropriate to provide preliminary evidence for a causal relationship between this study's independent and dependent variables of interest.

The population set is within selected church-run entities in Liberia, which comprise four (4) central offices, one-hundred and thirty-one (131) churches, one (1) hospital, one (1) university, and nine (9)

39 | This work is licensed under a Creative Commons Attribution 4.0 International License. 
schools. Thus, a single geographic region was used and offered the advantage of minimising the number of extraneous variables since these entities had similar characteristics. The sampling method used was purposive as the entities selected to participate in the study were only those that use audited financial statements: two central offices, the university, the hospital, and two main churches. The respondents were the executive committee members of each entity. These executives were selected as study participants because they are the ones who are called to make high-level decisions. The total number of committee members was ninety, and all were asked to participate in the study. Out of that number, sixty (60) surveys were usable.

The instrument chosen for the researcher to meet the specific research objective is a self-designed questionnaire from literature (Paul et al., 2004); Carraher \& Van Auken, 2013). The questionnaire comprises five sections: respondents' demographic information and financial statement information (6 items). For the "knowledge" section, the respondents were asked how knowledgeable they were about the five financial statements: Statement of Financial Position, Statement of Financial Activities, Statement of Changes in Net Assets, and the Statement of Cash-flow and the notes to the Financial Statements. The level of satisfaction was measured using four items. For example, "I am gratified that all the options have been analysed during the decision-making process." Lastly, the level of commitment was measured with three items. It was adapted from the decision commitment questionnaire from Dooley and Fryxell (1999).

The questionnaire was then submitted to three management experts involved in decision-making effectiveness to assess the questionnaire's validity in measuring the research questions. The questionnaire was corrected and reworked based on their input. The Cronbach's Alpha test was used to ensure interitem consistency of the measure of respondents' answers. The alpha indices were between .85 to .96 for the items on the questionnaire. Permission was sought from the administrators of each entity before the survey was administered. One of the researchers administered the questionnaire personally. The purpose of the study was explained to acquaint the participants with the nature of the study. The researcher collected the data within three weeks.

The study used descriptive statistics to analyse the general characteristics of the respondents (frequency, mean and standard deviation). In STATA Version 13, an Ordinal Logistic Regression (in particular, cumulative odds ordinal logistic regression with proportional odds) was undertaken to examine the relationship between 'Decision Commitment' and the predictor variables ('Quality' and 'Knowledge' and mediating variable ('Satisfaction'). The reason for analysing with Ordinal Logistic Regression is that the dependent variable is categorical and ordered. In addition, Ordinal Logistic Regression takes account of the order within our dependent variable and returns the contribution information of each independent variable. For the Mediation, a Path Analysis was used to determine the indirect effect of the independent variable on the dependent variable through the mediating variable.

\section{FINDINGS}

\section{Demographic Characteristics of the Sample}

The first part of the findings describes the characteristics of the respondents. Percentages were calculated for gender, years of age, the position of the respondents, and the number of years they served as decision-makers in the committees. According to Table 1 below, most (72\%) of the respondents are males, $70 \%$ are between 41-50 years, and $72 \%$ are not employees of the entities where they serve as board members. While $44 \%$ have served in these committees over seven years, $32 \%$ have been board members between 1 and 3 years only. 
Table 1: Demographic characteristics of the respondents

\begin{tabular}{llll}
\hline Position of the respondent & $\mathbf{\%}$ & Gender & $\mathbf{\%}$ \\
\hline President & 10.0 & Male & 71.7 \\
Executive Secretary & 8.3 & Female & 28.3 \\
Treasurer & 10.0 & & $\%$ \\
Ex Com/Board Member & 71.7 & Age & 1.7 \\
& & $21-30$ years & 13.3 \\
Years served as a member in the Board & $\%$ & $31-40$ years & 70.0 \\
$1-3$ yrs & 31.6 & $41-50$ years & 15.0 \\
$4-6$ yrs & 24.5 & 60 years \& above & \\
7 yrs \& above & 43.9 & & \\
\hline
\end{tabular}

\section{Association Between the Variables}

Spearman's rank correlation was used to test the degree of association between our variables because the variables are not linearly related, neither are they normally distributed. The Spearman correlations results (Table 2) show that there is no significant correlation between the independent variables (knowledge and quality) (p-value $=0.08$ ). However, 'satisfaction' was correlated with both independent variables ( $\mathrm{p}$-value $=0.03$ and less than 0.05, respectively). Commitment, the dependent variable, is also significantly correlated with satisfaction ( $\mathrm{p}$ value is less than 0.00 ).

Table 2: Degree of association between the variables used

\begin{tabular}{lll}
\hline Spearman Rho $(\mathbf{N}=\mathbf{5 9})$ & & \\
\hline & Correlation coefficient & Significance \\
\hline Commitment-knowledge & 0.22 & 0.09 \\
Commitment-quality & 0.003 & 0.98 \\
Commitment-satisfaction & 0.56 & $0.00^{* *}$ \\
Satisfaction-Knowledge & 0.28 & $0.03^{* *}$ \\
Satisfaction-Quality & 0.38 & $0.00^{* *}$ \\
Quality-Knowledge & 0.23 & 0.08 \\
\hline
\end{tabular}

\section{Ordinal Logistic Regression}

Ordered or ordinal logistic regression analysis was performed to measure the strength of the association between each independent and mediating variable and the dependent variable. The Table 3 below summarises the findings.

Table 3: Ordinal Logistic Regression analysis

\begin{tabular}{lllllll}
\hline Commitment & Odds ratio & Std Error & $\mathbf{Z}$ & $\mathbf{P}>|\mathbf{z}|$ & \multicolumn{2}{c}{ [95\% confidence interval] } \\
\hline Knowledge & 3.814896 & 2.08637 & 2.45 & 0.014 & 1.3061 & 11.1431 \\
Quality & $4.97-\mathrm{e}$ & .000 & -0.01 & 0.99 & 0 & \\
Satisfaction & 21.97053 & 21.97954 & 3.09 & 0.002 & 56.0958 & \\
\hline
\end{tabular}

41 This work is licensed under a Creative Commons Attribution 4.0 International License. 
The findings from the first set of variables show that the odds of executive committee members who understand financial statements and stating that they felt "commitment to the decision made" (versus the middle and low categories) was 3.814896 (95\% CI, 1.30605 to 11.14309$)$ times that of executive committee members with less knowledge of financial statements, a statistically significant effect, $p=0.014$. Thus, the knowledge of the decision-makers does affect their level of commitment to the decision. The implication is that if the decision-makers cannot understand the financial statements, they will not feel decision commitment once the decision is made.

The second set of variables is about commitment and quality. The findings indicate that quality does not have a statistically significant effect on commitment.

The third set of variables was about commitment and satisfaction. The odds of executive committee members with high levels of user satisfaction with the decision-making process, stating that they felt "commitment to the decision made" (versus the middle and low categories) was 21.97053 (95\% CI, 3.092358 to 156.0958 ) times that of executive committee members with low levels of user satisfaction, a statistically significant effect, $p=$ 0.002 .

Thus, the findings seem to indicate that the decision-makers would be more committed to the decision made because of the satisfactory experience of the decision-making process.

Table 4: Effect of knowledge and quality on satisfaction

\begin{tabular}{lllllll}
\hline Satisfaction & Odds ratio & Std Error & $\mathbf{Z}$ & $\mathbf{P}>|\mathbf{z}|$ & \multicolumn{2}{c}{ [95\% confidence interval] } \\
\hline Knowledge & 14.3333 & 16.6944 & 2.29 & 0.022 & 1.4619 & 140.5289 \\
Quality & 2.5 & 3.0311 & 0.76 & 0.45 & .2322 & 26.9133 \\
\hline
\end{tabular}

Concerning the effect of knowledge on satisfaction, the odds of executive committee members with high levels of user knowledge of financial statements stating that they felt "satisfied with the decision process" (versus the middle and low categories) was 14.3333 (95\% CI, 1.461941 to 140.5286 ) times that of executive committee members low levels of user knowledge, a statistically significant effect, $\mathrm{p}=$ 0.022. Thus, executive committee members are more satisfied with the decision-making process when they can understand and interpret the data provided by the financial statements. The executives are likely to contribute more to the discussion when they are aware of what is being discussed, thus can see their goals/expectations being met.

The fifth set of factors analyse the effect of quality on satisfaction. It is found that quality does not affect the level of satisfaction.
These results suggest that, although a higher quality of the financial statements may be associated with satisfaction and commitment, there is no causeeffect relationship between these variables. On the other hand, the results imply that the level of knowledge of the decision-makers may affect their level of satisfaction with the decision-making process and their level of commitment to the decisions taken. Following the initial analysis, we can deduce that knowledge and satisfaction are individually statistically significant predictors of commitment, while quality is not. Hence only satisfaction and knowledge were retained and used in the final model.

\section{Relationship Between Satisfaction, Knowledge, and Commitment}

In this case, "The odds of executive committee members of each entity sampled stating that they felt "commitment to the decision made" given they 
had high levels of user knowledge of financial statements for those with high levels of user satisfaction compared to those with low levels of user satisfaction is 2.527091, given the level of satisfaction remains constant (unchanged). The 95\%
CI includes the null, i.e., 1 , and the $\mathrm{p}=0.103$. The results show that when the variable "satisfaction" is added to the model, knowledge is no longer a predictor of commitment, as shown in the Table 5 below:

Table 5: The relationship between commitment and knowledge

\begin{tabular}{lllllll}
\hline Decision Commitment & Odds ratio & Std Error & $\mathbf{Z}$ & $\mathbf{P}>|\mathbf{z}|$ & \multicolumn{2}{c}{ [95\% confidence interval] } \\
\hline Knowledge & 2.527091 & 1.438952 & 1.63 & 0.103 & 0.8278239 & 7.71443 \\
\hline
\end{tabular}

\section{Path Analysis}

In order to measure the indirect effect of the independent variable on the dependent variable through the mediating variable, a path analysis was done. The path model diagram is shown in the figure below:

\section{Figure 1: Path Model diagram}

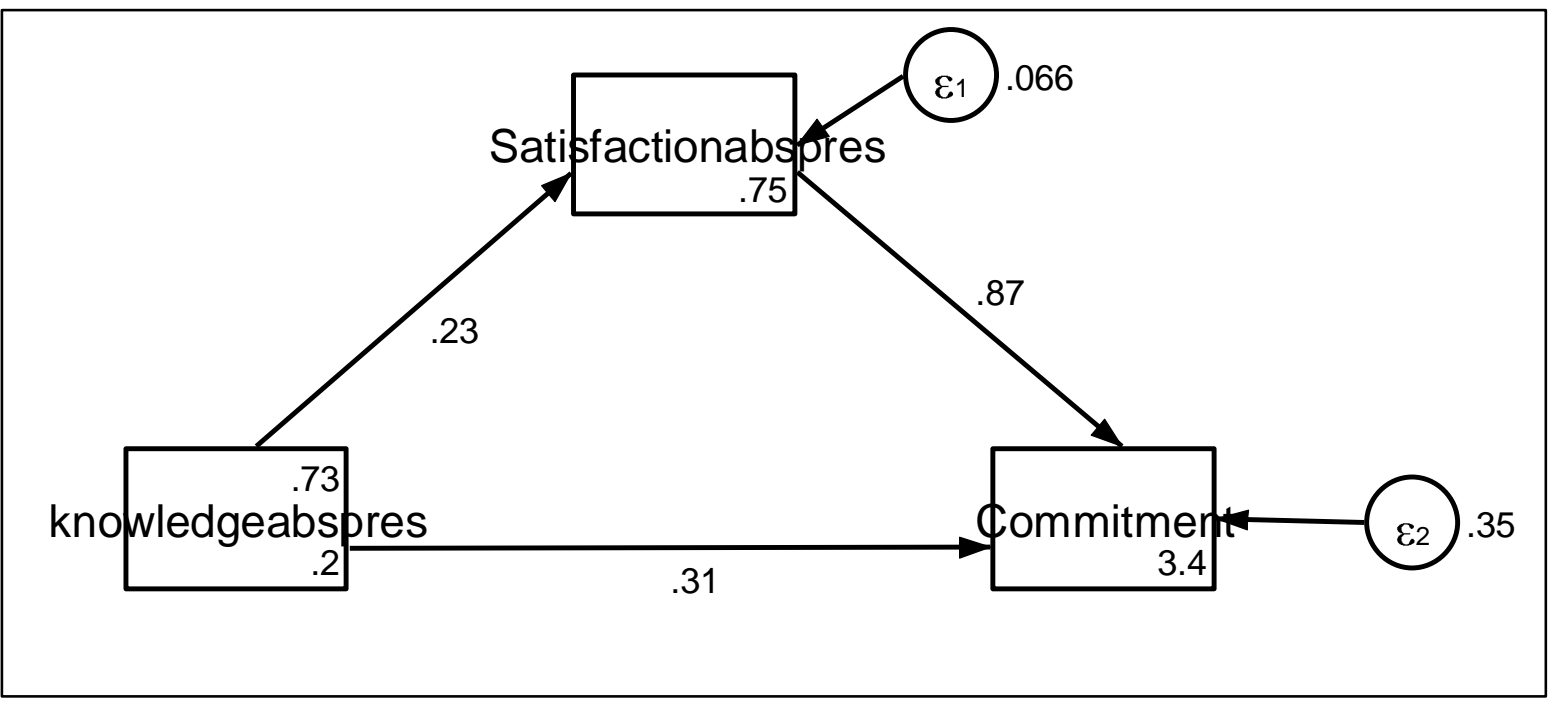

Table 6: The detailed path model

\begin{tabular}{lllllll}
\hline Direct effect & \multicolumn{1}{l}{} & & & \\
\hline Satisfaction & Coeff. & Std Error & $\mathbf{Z}$ & $\mathbf{P}>|\mathbf{z}|$ & {$[\mathbf{9 5 \%}$ confidence interval] } \\
\hline Knowledge & 0.2272727 & 0.0751634 & 3.02 & 0.002 & 0.799552 & .3745903 \\
\hline Commitment & Coeff. & Std Error & $\mathbf{Z}$ & $\mathbf{P}>|\mathbf{z}|$ & {$[\mathbf{9 5 \%}$ confidence interval] } \\
\hline Satisfaction & .8685714 & .2949766 & 2.94 & 0.003 & .2904278 & 1.446715 \\
Knowledge & .3144345 & .1843604 & 1.71 & 0.088 & -.0469052 & .6757743 \\
\hline Indirect effect & & & & & & \\
\hline Commitment & Coeff. & Std Error & $\mathbf{Z}$ & $\mathbf{P}>|\mathbf{z}|$ & {$[\mathbf{9 5 \%}$ confidence interval] } \\
\hline Satisfaction & No path & & & & & \\
Knowledge & .1974026 & .0936751 & 2.11 & 0.035 & .0139967 & .3808083 \\
\hline
\end{tabular}

43 This work is licensed under a Creative Commons Attribution 4.0 International License. 
East African Journal of Business and Economics, Volume 5, Issue 1, 2022

Article DOI: https://doi.org/10.37284/eajbe.5.1.545

\begin{tabular}{lllllll}
\hline Total effect & \multicolumn{7}{l}{} & & & \\
\hline Satisfaction & Coeff. & Std Error & $\mathbf{Z}$ & $\mathbf{P}>|\mathbf{z}|$ & {$[\mathbf{9 5 \%}$ confidence interval] } \\
\hline Knowledge & .2272727 & .0751634 & 3.02 & 0.002 & .0799552 & .3745903 \\
\hline Commitment & Coeff. & Std Error & $\mathbf{Z}$ & $\mathbf{P}>|\mathbf{z}|$ & \multicolumn{2}{l}{$[\mathbf{9 5 \%}$ confidence interval] } \\
Satisfaction & .8685714 & .2949766 & 2.94 & 0.003 & .2904278 & 1.446715 \\
Knowledge & .5118371 & .1837294 & 2.79 & 0.005 & .1517342 & .87194 \\
\hline
\end{tabular}

The coefficient for the direct effect of 'Knowledge' on 'Satisfaction' $=0.2272727(\mathrm{p}=0.002)$. Thus 'Knowledge' is a statistically significant positive predictor of 'Satisfaction.' Hence, 'Satisfaction' is a statistically significant positive predictor of 'Commitment' (coefficient $=0.8685714$ and $\mathrm{p}$-value $=0.003)$.

However, the findings indicate that the direct effect of 'Knowledge' on 'Commitment' is not significant (coefficient $=0.3144345 \mathrm{p}$-value $=0.088$ ). Thus, although 'Knowledge' is a positive predictor of 'Commitment,' it is not a direct influence.

The Table 6 above also shows the indirect effect computed as a product of path $\mathrm{A}$ and path $\mathrm{B}$ and used to evaluate the mediation effect. The coefficient is 0.1974026 ( $\mathrm{p}=0.035 ; 95 \%$ CI $0.0139969-0.3808083)$.

The findings seem to indicate that the majority of the effect of 'knowledge' on 'commitment' is mediated through 'satisfaction.' Based on the mediation analysis, we can conclude that the effect of 'knowledge' on 'decision commitment' is indeed mediated through 'satisfaction' as 'knowledge' is not shown to have any statistically significant direct effect on 'decision commitment.'

\section{CONCLUSION AND DISCUSSION}

This study focused on two factors necessary when it comes to using information for decision-making: the quality of the information and the knowledge of the decision-makers regarding the information being used. Financial information is a critical element of many organisations, including not-forprofit organisations, and the source of this information is primarily the set of financial statements. The study highlighted the effect of quality and the knowledge of interpreting the financial statements on the commitment to carry on the decisions taken and the mediating effect of satisfaction during the decision-making process.

The findings seem to point out that the quality of the financial statements is significantly associated with satisfaction. This finding is important for managers of not-for-profit organisations to consider. As they prepare for the meetings, they need to give specific instructions to the finance department to submit timely, complete, and accurate financial statements to committee members. The study also highlights that when decision-makers can read and understand the financial information contained in the financial statements, it helps in enhancing the satisfaction of the decision-making process. These two findings confirm other studies, where decision-makers' quality of information and knowledge are essential factors in decision-making.

The findings further highlight that unlike 'quality,' 'knowledge' seems to affect satisfaction with the decision-making process. However, there is no direct influence, which means that the members' level of expertise does not necessarily make them more committed to the decision. Rather, commitment can be expected only when the knowledge brings about satisfaction with the decision-making process. This finding resonates with a study by Santos et al. (2018), where they found that knowledge in and of itself is not associated with effective decision-making. 
Overall, these findings are useful to the not-forprofit organisations in that they seem to indicate that, when it comes to major financial decisions, there is much to do before and during an important committee meeting (Brinckerhoff, 2009). Before the meeting, quality financial statements must be produced (in terms of relevance and completeness) and submitted to the decision-makers on time. Executives must be prepared knowledge-wise to come to the decision table, including doing the necessary 'homework' and conducting preliminary discussions. The preliminary activities will not, in themselves, guarantee any commitment to the decision taken. The actual process of the meeting must be well organised and well-run to avoid any unnecessary hindrances and meet the expectations of all the attendees and thus meet their satisfaction. It is a serious business, and the employees (from the finance and administration departments) and the decision-makers need to be conscious of their responsibilities.

\section{Limitations and Recommendation for Further Studies}

One limitation of this study is the size of the sample. It is possible that the small sample size may not have allowed depicting the relationship between quality, satisfaction, and decision commitment if one truly does exist. Future studies could include a larger sample that would give more precision to the results and shed more light on the dynamics involved. Future studies could also consider the contextual variables such as organisational policies, organisational culture, and the environment within the organisation is operating as possible moderating variables since studies show that context influences commitment too.

\section{REFERENCES}

Akhtar, S., \& Liu, Y. (2018). SMEs' use of financial statements for decision-making: Evidence from Pakistan. Journal of Applied Business Research, 34(2), 381-392.
Bharati, P., \& Chaudhury, A. (2004). An empirical investigation of decision-making satisfaction in web-based decision support systems. Decision support systems, 37(2), pp. 187-197.

Brinckerhoff P. (2009). Mission-based Management: Leading your Not-for-Profit in the $21^{\text {st }}$ Century. ( $3^{\text {rd }}$ ed.). N.J.: John Wiley and Sons Inc.

Carneiro, J., Santos, R., Marreiros, G., \& Novais, P. (2014). Understanding Decision Quality through Satisfaction. Highlights of Practical Applications of Heterogeneous Multi-Agent Systems. The PAAMS Collection, pp. 368-377

Carraher, S., \& Van Auken, H. (2013). The use of financial statements for decision-making by small firms. Journal of Small Business \& Entrepreneurship, 26(3), 323-336. DOI: 10.1080/08276331.2013.803676

Dean Jr, J. W., \& Sharfman, M. P. (1996). Does decision process matter? A study of strategic decision-making effectiveness. Academy of management journal, 39(2), 368-392.

de la Torre-Ruiz, J. M., Ferrón-Vílchez, V., \& Ortiz-de-Mandojana, N. (2014). Team decisionmaking and individual satisfaction with the team. Small group research, 45(2), 198-216.

Dooley, R. S., \& Fryxell, G. E. (1999). Attaining decision quality and commitment from dissent: The moderating effects of loyalty and competence in strategic decision-making teams. Academy of Management Journal, 42, 389-402

Dooley, R. S., Fryxell, G. E., \& Judge, W. Q. (2000). Belaboring the not-so-obvious: Consensus, commitment, and strategy implementation speed and success. Journal of management, 26(6), 1237-1257.

Drummond, H. (2014). Escalation of Commitment: When to Stay the Course? The Academy of 
Management Perspectives 28(4), 430-446. http://dx.DOI.org/10.5465/amp.2013.0039

Harrison, D. S., \& Killough, L. N. (2006). Decision outcomes under activity-based costing: Presentation and decision commitment interactions. Advances in Management Accounting, 15, 169- 193.

Harrison Jr, W. T., Horngren, C. T., \& Thomas, C. W. (2014). Financial accounting. Pearson Education.

Lang, A. S., Ricciardella, T., Klumpp, L., \& Eisig, W. D. (2017). How to read nonprofit financial statements: A practical guide. NY: John Wiley and Sons.

McDonald, R. E., Weerawardena, J., Madhavaram, S., \& Mort, G. S. (2015). From "virtuous" to "pragmatic" pursuit of social mission: A sustainability-based typology of nonprofit organisations and corresponding strategies. Management Research Review (38),9 pp. 970991.

Nutt, P. C., \& Wilson, D. C. (Eds.). (2010). Handbook of decision-making (Vol. 6). John Wiley \& Sons.

Osadchy E. A., Akhmetshin E. M., Amirova E. F., Bochkareva T. N, Gazizyanova Yu Gazzaniga., Yumashev A.V (2018). Financial Statements of a Company as an Information Base for DecisionMaking in a Transforming Economy. European Research Studies Journal Volume XXI, Issue 2, pp. 339-350.

Paul, S., Seetharaman, P., \& Ramamurthy, K. (2004, January). User satisfaction with system, decision process, and outcome in GDSS based meeting: an experimental investigation. In 37th Annual Hawaii International Conference on System Sciences, 2004. Proceedings of the (pp. 37-46). IEEE.
Reinig B. A (2003). Toward an Understanding of Satisfaction with the Process and Outcomes of Teamwork. Journal of Management Information Systems, 19(4), pp. 65-83.

Russ, F. A., McNeilly, K. M., \& Comer, J. M. (1996). Leadership, decision-making and performance of sales managers: A multi-level approach. Journal of Personal Selling \& Sales Management, 16(3), 1-15.

Sanders, M. L., \& McClellan, J. G. (2014). Being business-like while pursuing a social mission: Acknowledging the inherent tensions in US nonprofit organising. Organisation, 21(1), 6889.

Santos, J. P. F. D., Pires, A. M. M., \& Fernandes, P. O. (2018). The importance to financial information in the decision-making process in company's family structure. Contaduría $y$ administración, 63(SPE2), 1091-1113.

Shagari, S., \& Dandago, K. (2013, October). Decision Usefulness Approach To Financial Reporting, A Case For The General Public. In The 14th Asian Academic Accounting Association (4As) Annual International Conference, holding at Penang, Malaysia October (pp. 27-30).

Shalimova, N., \& Kuzmenko, H. (2016). Qualitative characteristics and principles of financial reports in the context of disclosure of information about the enterprise as a subject of tax relations. Economics \& Education, 01(02), pp. 30-35.

Simons, T., Pelled, L. H., \& Smith, K. A. (1999). Making use of difference: Diversity, debate, and decision comprehensiveness in top management teams. Academy of management journal, 42(6), 662-673.

Sontag-Padilla, L. M., Staplefoote, L., \& Morganti, K. G. (2012). Financial sustainability for

46 This work is licensed under a Creative Commons Attribution 4.0 International License. 
East African Journal of Business and Economics, Volume 5, Issue 1, 2022

Article DOI: https://doi.org/10.37284/eajbe.5.1.545

nonprofit organisations: A review of the literature. RAND.

Türel, A. (2010). Timeliness of financial reporting in emerging capital markets: Evidence from Turkey. Ístanbul Üniversitesi İsletme Fakültesi Dergisi, 39(2), 227-240.

Ullah, H., Khonadakar, J. A. \& Fahim, S. T. (2014). Role of Accounting Information in Strategic Decision-making in Manufacturing Industries in Bangladesh. Global Journal of Management and Business Research: D Accounting and Auditing, 14(1), p. 8-22.

Uzonwanne, F. C. (2016). Rational model of decision making. Global encyclopedia of public administration, public policy, and governance. Springer International. https:/doi. org/10.1007/978-3-319-31816-5_2474-1.

Uzonwanne, F. C. (2016). Rational model of decision making. Global encyclopedia of public administration, public policy, and governance. Springer International. https:/doi. org/10.1007/978-3-319-31816-5_2474-1.

Wang'ombe, D. (2005). Advanced Accounting: theory and practice. Nairobi: Focus Publishers Ltd.

Wolf, T. (2012). Managing a nonprofit organisation: Updated twenty-first-century edition. Simon and Schuster.

Worth, M. J. (2019). Not-for-profit Management: Principles and Practice. ( $5^{\text {th }}$ ed.). SAGE Publications.

Zager, K., \& Zager, L. (2006). The role of financial information in decision making process. Innovative Marketing, 2(3), 35-40.

Zayol, P. I., Agaregh, T., \& Eneji, B. E. (2017). Effect of financial information on investment decision making by shareholders of banks in
Nigeria.IOSR Journal of Economics and Finance, 8(3), 20-31.

Ziotti, V. C., \& Leoneti, A. B. (2020). Improving commitment to agreements: The role of group decision-making methods in the perception of sense of justice and satisfaction as commitment predictors. Pesquisa Operacional, 40.

47 | This work is licensed under a Creative Commons Attribution 4.0 International License. 